\title{
LĖTINIŲ NEUŽKREČIAMUৃJŲ LIGŲ VALDYMO GALIMYBĖS PIRMINĖJE ASMENS SVEIKATOS PRIEŽIŪROJE
}

\author{
Rita Baltušienė, Marius Buitkus, Vytautas Dringelis, \\ Aldona Kaltanienè, Tatjana Subočiūtè-Stuliova \\ Lietuvos Respublikos vidaus reikalu ministerijos Medicinos centras
}

\begin{abstract}
Raktažodžiai: dauginis ligotumas, lètinès neužkrečiamosios ligos, lėtinių ligų valdymas, atvejo vadyba, integruotos priežiūros modeliai, paciento įgalinimas.
\end{abstract}

\begin{abstract}
Santrauka
Pirminès sveikatos priežiūros paslaugų teikejjai šiuo metu nèra pasirengę spręsti sudètingų senėjančios visuomenès sveikatos problemų, tad daugelis pasaulio šalių, siekdamos pagerinti paslaugų prieinamumą ir kokybę, ivvairiais būdais stiprina pirminès sveikatos priežiūros grandị. Tyrimo tikslas - rasti mokslu pagrịstu írodymu apie intervencijų ị pirminę sveikatos priežiūrą veiksmingumą, siekiant patenkinti pacientų, vienu metu sergančių dviem ir daugiau neužkrečiamujų lętinių ligų, poreikius. Tiriamasis laikotarpis 2005-2021 metai. Tyrimui naudoti Lietuvoje ir užsienio šalyse atliktų mokslinių tyrimų duomenys, atitinkantys nagrinejjamą temą ir nacionaliniai teisès aktai, kuriuose reglamentuojamas lètinių neužkrečiamujų ligų valdymas. Rezultatai atskleidè keturias lètinių ligų valdymo gerinimo galimybes: 1) šeimos gydytojo komandos stiprinimas, įtraukiant $i$ ją slaugos ir socialinių paslaugų darbuotojus ir perduodant jiems dalį funkcijų; 2) išplèstinès praktikos slaugytojo integravimas ị pirminę grandị; 3) atvejo vadybos modelio taikymas; 4) paciento igalinimas savarankiškai valdyti ligą.

Išvada - i pacientą orientuota integruota sveikatos priežiūra, atvejų vadyba ir partnerystė su pacientais, igalinant juos sveikatai palankia elgsena savarankiškai valdyti ligą, galètų sumažinti sergančiųu priklausomybę nuo institucinès globos, o kartu ir sveikatos priežiūros išlaidas, išvengiant nebūtino hospitalizavimo.
\end{abstract}

\section{Ivadas}

Dauginis ligotumas, dažniausiai apibrěžiamas kaip dvi ar daugiau lètinių ligų bei sveikatos sutrikimų, tuo pačiu metu diagnozuojamų vienam asmeniui [1], kelia daug problemų pacientui ir sveikatos priežiūros įstaigoms. Ilgèjant gyvenimo trukmei, šis reiškinys dažnèja. Keliomis ligomis serga
55-98 proc. senyvo amžiaus pacientų [2], todèl dauginis ligotumas tampa pagrindine grèsme gyventojų sveikatai ir didžiausiu iššūkiu sveikatos priežiūros sistemoms visame pasaulyje. Sergančiųjų keliomis ligomis sveikatos būklè dažniausiai yra prastesnè nei tų, kurie serga viena lètine liga [3]. Vyresniems nei 80 metų žmonėms dažnai diagnozuojama daug lètinių ligų bei jų sukeliamų sveikatos sutrikimų, kontroliuojamų daugybès vaistų [4]. Kai yra daugiau nei dvi kartu esančios patologinès būklès, susijusios su įvairių vaistų vartojimu, galima netinkama vaistų sąveika, didejja nepageidaujamų reakcijų rizika, todèl, didejjant dauginio ligotumo atvejų, sveikatos priežiūros sistemos ieško tinkamiausio integracijos ir bendradarbiavimo principais pagrịsto lètinių neužkrečiamujų ligų valdymo modelio.

Tyrimo tikslas - rasti mokslu pagrịstų ịrodymų apie intervencijų i pirminę sveikatos priežiūrą veiksmingumą, siekiant patenkinti pacientų, vienu metu sergančių dviem ir daugiau neužkrečiamųjų lètinių ligų, poreikius.

\section{Tyrimo medžiaga ir metodai}

Tyrimui naudoti Lietuvoje ir užsienio šalyse atliktų mokslinių tyrimų duomenys, atitinkantys nagrinejjamą temą ir nacionaliniai teisès aktai, kuriuose reglamentuojamas lètinių neužkrečiamujų ligų valdymas. Pasirinktas aprašomojo tyrimo metodas. Elektroninè literatūros paieška atlikta naudojantis PubMed (Medline), ScienceDirect, Cochrane Library elektroninėmis duomenų bazèmis. Nagrinejjimui atrinkti straipsniai apie dauginị ligotumą ir intervencijas, kuriomis siekta pagerinti lètinių neužkrečiamujų ligų valdymą pirminejje sveikatos priežiūroje, slaugytojų vaidmens svarbą šiame procese. Tiriamasis laikotarpis 2005-2021 metai.

\section{Tyrimo rezultatai}

Dauginis ligotumas dažniausiai apibrěžiamas kaip du ar daugiau vieno asmens lètinių sveikatos sutrikimų. Jis susijęs su gyvenimo trukmès ilgejimu, visuomenès populiacijos senėjimu, sergančiujų funkciniu nuosmukiu ir didesniu sveikatos priežiūros paslaugų, tarp jų ir skubiosios pagalbos, 


\section{4}

naudojimu $[5,6]$. Pacientai, sergantys dviem, o ypač turintys daugiau gretutinių ligų, dažniau ir ilgiau gydomi nei sergantieji viena liga, per jauni miršta [6,7].

Grupe tyrejų, išanalizavusi 10 metų laikotarpio klinikinius 120480 pacientų ( $\geq 55$ metų) duomenis, nustate bendrą 86 proc. dauginio ligotumo rodikli pacientams, sergantiems $\geq 1$ lètine liga, kuris svyravo nuo 70 (migrena) iki 98 proc. (širdies nepakankamumas), o 38 proc. sudare $\geq 4$ lètinès ligos. Dauginis ligotumas buvo nustatytas 83 proc. 55-69 metų pacientų [8]. Šioje studijoje nustatyta daug reikšmingų širdies nepakankamumu sergančių pacientų ligos paplitimo santykių, svyruojančių nuo 1:2 iki 7:7, iš kurių didžiausias lètinès obstrukcinès plaučių ligos ir širdies ritmo sutrikimo santykis. Cukriniu diabetu, demencija ar migrena sergančiu pacientų santykis buvo širdies nepakankamumo-regos sutrikimo 2:1, širdies nepakankamumo-depresijos 3:9, nugaros (kaklo) - depresijos 2:1 ir kt. [9]. B. Urbšio (2020) tyrimas atskleidè dauginèmis lėtinèmis ligomis sergančiu pacientų vartojamų vaistų skaičių, grupes bei dažniausiai pasitaikančias tarpusavio sąveikas. Ištyręs 150 (>65 m. 77,6\%; <65 m. 22,4\%) dauginèmis ligomis sergančių šeimos medicinos klinikos pacientų, tyrèjas nustatè, kad 71,33 proc. tiriamuju pasireiškè polifarmacija, dažniau vyresniems nei $65 \mathrm{~m}$. pacientams. Vidutiniškai pacientai vartojo daugiau nei 7 vaistines medžiagas, kurių kiekis didèjo, didejjant lètinių ligų skaičiui. Daugiausia vaistų vartojo sergantieji daugiau nei 7 lètinèmis ligomis. Visi tiriamieji vartojo bent vieną receptinị preparatą, o šiek tiek daugiau nei pusè - nereceptinius, mažiau nei dešimtadalis - žolinius, trečdalis apklaustujų vartojo maisto papildus. Daugiausia vaistų vartojo sergantieji širdies ir kraujagyslių ligomis. Daugiau nei keturis penktadalius visų vaistų tarpusavio sąveikų sudare vidutinės rizikos sąveikos; mažos ir didelės rizikos sąveikos sudarẻ beveik penktadalị visų, o didžiausios sąveikos 1,13 proc. visų sąveikų. Daugiausia vidutinės rizikos vaistų tarpusavio sąveikų nustatyta tarp biguanidų-AKF inhibitorių; tarp mažos rizikos sąveikų vyravo $\mathrm{K}$ vitamino antagonistų-aldosterono antagonistų bei sulfonamidu -AKF inhibitorių tarpusavio veikimas; tarp didelès rizikos buvo stebima selektyvių $\beta 1$ adrenoblokatorių-imidazolino receptorių agonistų tarpusavio sąveika, o pavojingiausia sąveika rasta kartu skiriant selektyvius $\beta 2$ adrenoreceptorių agonistus-neselektyvius betaadrenoblokatorius [10].

Šeimos medicinos paslaugos kol kas labiau orientuotos ị sveikatos problemų sprendimą, o ne ị sveikatos stiprinimą ar išsaugojimą [11], todèl pirminès sveikatos priežiūros paslaugų teikèjai dar nèra pasirengę spręsti sudètingų senejjančios visuomenès sveikatos problemų [12], o daugelis pasaulio šalių, siekdamos pagerinti paslaugų prieinamumą ir kokybę, ìvairiais būdais stiprina pirminès sveikatos priežiūros grandi [13]. Lietuvoje suformuotas lètinių neužkre- čiamujų ligų valdymo ir integruotų sveikatos priežiūros paslaugų teikimo teisinis pagrindas. Nuo $2006 \mathrm{~m}$. gyventojams sudarytos galimybès naudotis penkiomis iš Privalomojo sveikatos draudimo fondo finansuojamomis ligų prevencijos programomis [14], parengti teisès aktai, reglamentuojantys integruotų slaugos ir socialinių paslaugų teikimą namuose [15], 2008 m. patvirtinta Valstybinè lètinių neinfekcinių ligų profilaktikos programa, orientuota ị labiausiai paplitusių ligų prevenciją ir gyventojų atsakomybès už savo sveikatą didinimą [16]. Ilgalaikị pacientų, sergančių lètinèmis ligomis, sveikatos būklès stebejjimą reglamentuoja LR sveikatos apsaugos ministro $2014 \mathrm{~m}$. vasario $28 \mathrm{~d}$. įsakymas $\mathrm{Nr}$. V-288 Dèl ilgalaikio pacientų, sergančių lètinèmis ligomis, sveikatos būklès stebejjimo tvarkos aprašo patvirtinimo [17]. Reguliarus paciento sveikatos būklès stebejjimas skiriamas po aktyvaus gydymo. Stebėjimą nustatytu periodiškumu vykdo gydytojas specialistas, kuris pagal poreiki skiria pacientui tyrimus, gydymą ir teikia išvadą bei rekomendacijas šeimos gydytojui dèl tolesnès paciento sveikatos priežiūros (1 pav.). Priežiūros tęstinumą pacientams, turintiems sudètingų poreikių (dažnai lankosi ịstaigoje, dažnai kreipiasi dèl skubiosios pagalbos, serga keliomis ligomis ir pan.) užtikrina šeimos gydytojo komanda [18].

Problemos sprendimą sunkina tai, kad lètinès neužkrečiamosios ligos ilgai kliniškai nepasireiškia, ypač nesant fizinès ir (ar) psichinès ịtampos, tačiau lètai progresuodamos sutrikdo asmens biopsichosocialines funkcijas ir buvęs tarsi sveikas žmogus, staiga tapęs neigaliu (infarktas, insultas), labai sunkiai adaptuojasi fiziškai ir psichologiškai. Tradicinis sveikatos priežiūros modelis tokiais atvejais yra nepakankamas, nes neaprépia visų tokiems ligoniams reikalingos pagalbos sričių [19], tačiau pripažįstama, kad prevencines intervencijas geriausiai pasirengę vykdyti pirminès sveikatos priežiūros gydytojai [20], jie teikia apie 68 proc. visos pacientų priežiūros [21]. Pastebima, kad pirminè sveikatos priežiūra klinikinejje praktikoje nepakankamai taiko mokslo rekomendacijas ir prevencines priemones [22], nes, panašu, jai tenka neįmanoma užduotis. Kone prieš dvidešimtmetị buvo apskaičiuota, kad norint ịvykdyti visas rekomendacijas, pirminès sveikatos priežiūros specialistams létinèms ligoms valdyti prireiktų 11 valandų per parą [23] ir dar 7 valandų prevencinems paslaugoms [24]. Nuo to laiko rekomendacijų tik daugèjo. Nuo 1984 iki 2008 m. kardiologijos rekomendacijų skaičius išaugo 48 procentais [25]. Panašiu laikotarpiu PubMed paskelbtų rekomendacijų skaičius padidejo nuo 73 iki 7508 [26]. Radosi tyrëjų, teigiančių, kad biomedicininio modelio (kai pirmenybè teikiama ligų gydymui) įsigalèjimas trukdo pirminès sveikatos priežiūros, ligų prevencijos ir sveikatos ugdymo igyvendinimui [27].

J. Černiauskaitè (2014), tyrusi LSMU Kauno klinikų 
šeimos medicinos klinikoje dirbančių šeimos gydytojų ir pacientų požiūrị i medicininès konsultacijos tikslus bei pacientui skirto laiko panaudojimo veiksmingumą, atskleidè, kad gydytojų konsultacijų laiko panaudojimo kliuvinių yra ne tik gydytojo ir paciento sąveikoje, bet ir netobuloje sveikatos priežiūros sistemoje [28]. I. Jakubynaitè ir S. Kaselienè (2016), ištyrusios Alytaus apskrities poliklinikose ambulatorines paslaugas teikiančių gydytojų specialistų požiūrị i šeimos gydytojų išduodamų siuntimų pagrịstumą, padare prielaidą, kad šeimos gydytojai tinkamai neatlieka visų jiems šeimos gydytojo medicinos normoje priskirtų funkcijų ir netinkamai užpildo siuntimus, sunkindami gydytojų specialistų darbą. Šeimos gydytojai, nepanaudoję visų kompetencijų ligonio ištyrimo ir ligos diagnozavimo srityje, daugeli pacientų ị specialistų konsultacijas siunčia nepagrịstai, konsultacijos trunka ilgiau ar paskiriami keli apsilankymai, nes gydytojams specialistams tenka iš naujo rinkti informaciją, dubliuoti tyrimus, kurių rezultatai šeimos gydytojams jau žinomi [29]. E. Peičiaus ir A. Kučinskaitès (2014) tyrimas išryškino lètinėmis neužkrečiamosiomis ligomis sergančio paciento atsakomybės už savo sveikatą supratimo, sveikatos būklès rimtumo nesuvokimo problemą. Pacientai dažnai ne tik neịvertina savo ligos sudètingumo, bet ją ignoruoja, todèl dažnas, vos pajutęs sveikatos pagerèjimą, nustoja vartoti vaistus ar juos vartoja nereguliariai, todèl dèl savo nesupratingumo gali paskatinti rimtas komplikacijas ir paūmejjimus. Pacientų per mažas dėmesys savipriežiūrai ir savikontrolei, nereguliarus vaistų vartojimas, gydytojo nurodymų nevykdymas, atvirumo trūkumas, nesveikas gyvenimo būdas ir per trumpa konsultacijos trukmè - tai priežastys, kurių šalinimas galètų gerinti sveikatos priežiūros rezultatus [30].

Šeimos gydytojo komandos papildymas. Sklandžiam darbui užtikrinti būtina suformuoti visą šeimos gydytojo komandą, itraukiant i ją slaugos ir socialinių paslaugų darbuotojus ir perduoti jiems dali funkcijų [31]. Analogiška rekomendacija pateikiama Valstybineje audito ataskaitoje, kurioje sakoma, kad kai kurias šeimos gydytojų funkcijas, tiesiogiai nesusijusias su ligų diagnostika ir gydymu, verta pavesti kitiems darbuotojams, pavyzdžiui, vadybininkams, administratoriams, kad šeimos gydytojai daugiau laiko skirtu darbui pagal kompetenciją, dirbtų efektyviau, daugiau laiko skirtų gydomajam profilaktiniam darbui [32].

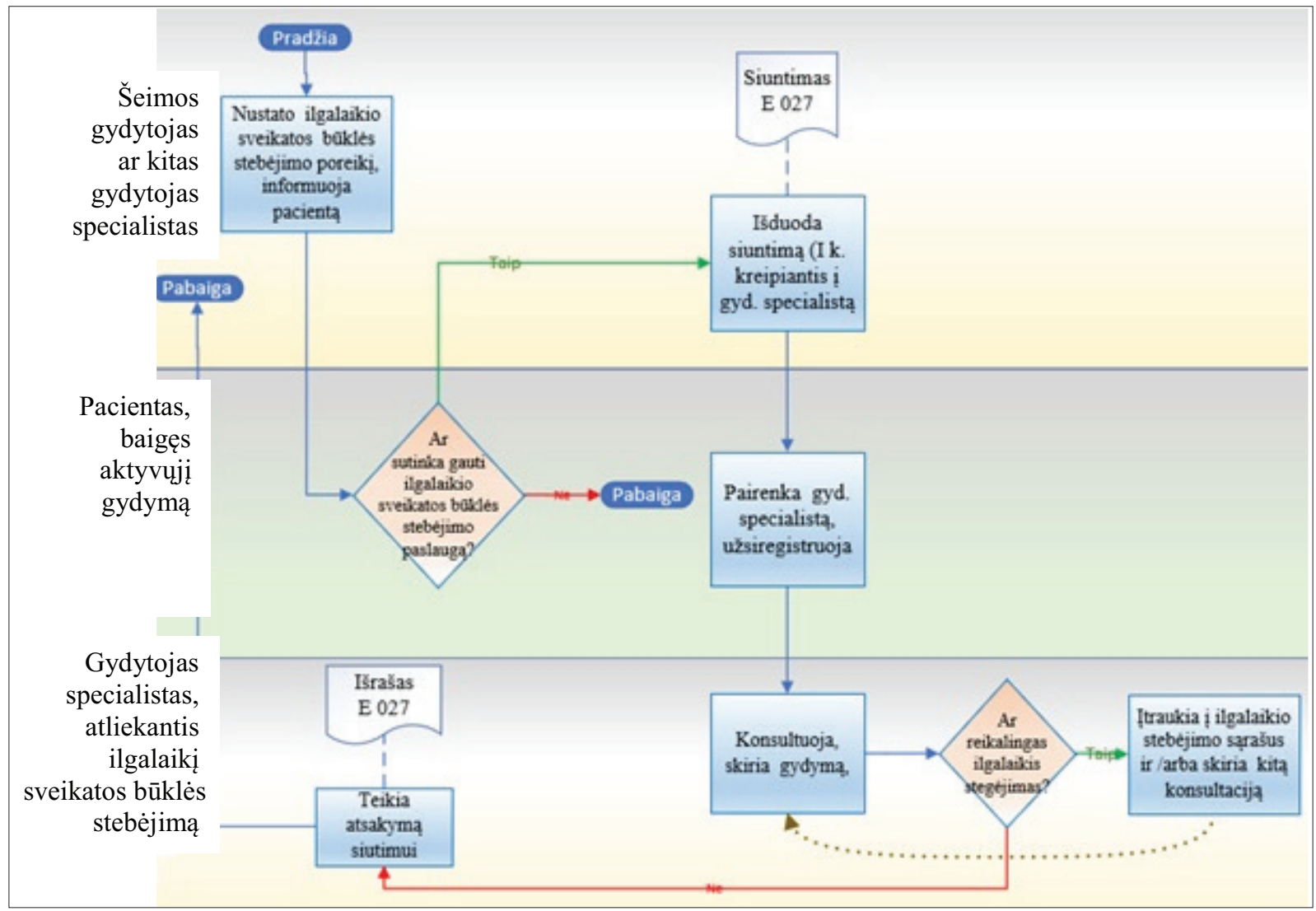

1 pav. Sergančiujų lėtinėmis ligomis sveikatos būklès stebėsenos schema

Šaltinis:pagal https://sam.lrv.lt/lt/veiklos-sritys/asmens-sveikatos-prieziura/pirmine-ambulatorine-asmens-sveikatos-prieziura/seimos-gydytojo-komandos-paslaugos 


\section{6}

Išplėstinės praktikos slaugytojo integravimas. Spręsdamos sveikatos priežiūros organizavimo problemas kaimo vietovèse ar mažuose miesteliuose, kur labiau jaučiamas šeimos gydytojų stygius, ar būtina sumažinti per dideli jų darbo krūvị ir pagerinti paslaugų prieinamumą, daugelis šalių rekomenduoja ị pirminès asmens sveikatos priežiūros grandị integruoti išplèstinès praktikos slaugytojo pareigybę [33]. M. Laurant su bendraautoriais (2018) paskelbè straipsni, kuriame išanalizavo 18 atsitiktinių imčių tyrimus, vertinusius išplèstinès praktikos slaugytojų, igalintų perimti dali gydytojų darbų, kuriems nebūtina gydytojo kompetencija, ittaką sveikatos priežiūros procesams ar gydymo rezultatams. Tyrejjai nustate, kad ịgalinti savarankiškai dirbti išplèstinès praktikos slaugytojai, prižiūrẻdami sergančiuosius širdies ligomis, diabetu, reumatu ir turinčius aukštą kraujospūdị, pasiekè panašių sveikatos rezultatų, kaip ir šeimos gydytojai: sumažejo gydytojų darbo krūvis, gydymo išlaidos, pagerèjo informacijos pacientui teikimas ir paslaugu prieinamumas, padidinęs pacientų pasitikèjimą sveikatos priežiūros ịstaiga ir pasitenkinimą paslaugomis [34].

Lietuvoje išplèstinès praktikos slaugytojo medicinos norma MN 160:2017 patvirtinta 2017 metais [35], todèl radosi mokslinių tyrimų, vertinančių praktines šių specialistų integravimo galimybes ị pirminès sveikatos priežiūros sistemą. A. Dubicka ir kt. (2021) tyrè veiksnius, kurie gali trukdyti arba padèti integruoti išplèstinès praktikos slaugytoją ị pirminę sveikatos priežiūros įstaigą. Grupé tyrẻjų atliko mokslinių straipsnių šia tema analizę, kuri parodè, kad daugelyje šalių gydytojų pakeitimas išplèstinès praktikos slaugos specialistais tapo ịprastinis dèl gydytojų trūkumo, pagerinęs sveikatos priežiūros prieinamumą, ypač sergančiujų lètinėmis ligomis. Tyrimas atskleide, kad gydytojams sunku perduoti pacientų priežiūrą išplèstinès praktikos slaugytojams, nes abejoja jų kompetencija, tačiau gydytojai, jau dirbantys komandoje su išplèstinès praktikos slaugytojais, pripažino, jog integravus šiuos specialistus ị pirminès sveikatos priežiūros grandị, sumažèja gydytojų darbo krūvis, yra daugiau laiko ūminių būklių konsultacijoms, pagerèja gydymo tęstinumas [36], tad sveikatos priežiūros sistemoje turi būti integruota organizacinè struktūra, stiprinanti gydytojų ir slaugytojų darbo santykius [37].

Atvejo vadybos modelio taikymas. Atvejo vadybą sveikatos priežiūros paslaugų teikimo sistemose Amerikos atvejo vadybos asociacija (angl. American Case Management Assocciation) apibrèžia kaip integralų bendradarbiavimo pagrindu sukurtą praktinị modelį, kai atvejo vadybininkas, naudodamasis komunikacijos priemonèmis ir turimais ištekliais, orientuodamasis ị individualius asmens ir šeimos poreikius, ịvertina paciento galimybes pasirinkti jam reikiamas paslaugas, kurias vèliau planuoja, koordinuoja jų vykdymą ir vertina efektyvumą, siekdamas saugių, kokybiškų ir ekonomiškai efektyvių rezultatų. Tai veikla, pagrịsta tarpdiscipliniškumu ir skirtingų sričių specialistų bendradarbiavimu, kadangi dirbti su pacientu ịtraukiami įvairūs subjektai: slaugytojai, gydytojai, pacientas, socialinis darbuotojas ir kiti specialistai, bendruomenè [38]. S. Smith ir kt. (2012) aprašè 10 atsitiktinių imčių kontroliuojamų tyrimų, aprèpusių 3407 pirminès priežiūros pacientus, vienu metu turinčius dvi ar daugiau ligų bei sveikatos sutrikimų. Buvo tiriamos įvairios kompleksinès intervencijos. Dviejuose tyrimuose aprašytos intervencijos pacientams, turintiems specifinių gretutinių ligų. Aštuoni tyrimai buvo skirti dauginiam vyresnio amžiaus pacientų ligotumui nagrinèti. Visi tyrimai apèmè sudètingas intervencijas su keliais komponentais. Šešiuose iš 10 tyrimu vyraujantis komponentas buvo priežiūros paslaugų teikimo organizavimo pakeitimas, dažniausiai taikant atvejo vadybą arba sustiprinant daugiadisciplininį komandinị darbą. Keturių tyrimų intervencijos komponentai daugiausia buvo orientuoti ị pacientą. Rezultatai parodè, kad sunku pagerinti šios populiacijos rezultatus, tačiau intervencijos, nukreiptos i tam tikrus gretutines ligas sukeliančius rizikos veiksnius arba su dauginiu ligotumu susijusius funkcinius sunkumus, gali būti veiksmingesnès [3].

Lietuvos sveikatos sistemos 2011-2020 m. metmenyse priimtos sveikatos priežiūros vadybos gerinimo nuostatos paskatino ịstaigas sukurti ir išbandyti pirminès sveikatos priežiūros veiklos integracijos atvejo vadybos modelị [39]. Tai buvo naujas dalykas Lietuvos asmens sveikatos priežiūros įstaigoms. Netrukus K. Štaras ir T. Vedlūga (2012) paskelbė straipsni, kuriame pristate atvejo vadybos sampratą, išnagrinejjo taikomus atvejo vadybos modelius ir pateikè VšI Centro poliklinikos atvejo vadybos patirties studiją, ivertindami šio praktikoje išbandyto modelio tinkamumą ir efektyvumą, jo naudą pacientams, gydytojo ir slaugytojo komandai bei įtaką asmens sveikatos priežiūros paslaugu kokybei. Autoriai priejo prie išvados, kad atvejo vadybos principas taikomas pagal skirtingus modelius, todèl, siekiant modelio efektyvumo, svarbu ji tinkamai suprojektuoti, atsižvelgiant ị finansines galimybes, teisinę aplinką, konkrečias sąlygas ir tinkamus veiksnius [40].

S. Norkienè ir kt. (2019) tyré šeimos gydytojų požiūrị i atvejo vadybos modelio taikymą, gerinant pirminès sveikatos priežiūros paslaugų prieinamumą ir kokybę. Išnagrinèję sveikatos priežiūros paslaugų teikimo patirtį užsienio šalyse, tyrejjai pažymėjo atvejo vadybos metodo prasmę ir reikalingumą. Tyrimo rezultatai parode, kad pirminès sveikatos priežiūros specialistai daug darbo laiko skiria veiklai, tiesiogiai nesusijusiai su sveikatos priežiūros paslaugų teikimu, todèl mažiau jo tenka pacientams, ligų prevencijai, diagnostikai ir gydymui. Taikant atvejo vadybos metodą, kiekvienas pa- 
cientas šeimos gydytojo grandyje turètų vadybininką kaip pagalbininką, organizatorių ir koordinatorių, gebanti padèti pacientui visą jo gydymosi laikotarpị. Atvejo vadybininkas perimtų ir dalị šiuo metu dideliu krūviu dirbančių šeimos gydytojų funkcijų, o tai lemtų geresnę sveikatos priežiūros paslaugų kokybę ir keltų pacientų pasitenkinimą teikiamomis paslaugomis, kadangi gydytojai didesnę darbo laiko dali galètų skirti savo tiesioginių pareigų vykdymui [41].

S. Savickaitè ir A. Česas (2020) pažymèjo, kad pasaulinè praktika ir tyrimai rodo atvejo vadybos vertę ir naudą, siekiant geriau spręsti onkologinių ligonių sveikatos priežiūros problemas.Tyrèjai aprašè Klaipėdos universitetinèje ligoninejje sukurtą, išbandytą ir praktikoje pasiteisinusị itin sẻkmingą strateginį sveikatos priežiūros sprendimą - pirminių onkologinių ligonių atvejo vadybos modelį. Šio modelio taikymas prisideda prie pacientų išgyvenamumo ir pasitenkinimo teikiama priežiūra didinimo, specialistų darbo kokybės gerinimo, o kartu ir prie antrinès ir tretinès sveikatos priežiūros grandžių krūvio mažinimo [42].

Sveikatos priežiūros organizacijose atvejo vadybos modelis vis dažniau taikomas kaip kompleksinių poreikių turinčių asmenų sveikatos priežiūros kokybės gerinimo priemonė [42]. Atvejų vadyba unikaliai prisideda prie sveikatos priežiūros, socialinių paslaugų ir kitų sektorių paslaugų integravimo ir teikia paramą žmonèms, turintiems sudètingų sveikatos būklių [43], tačiau taikant atvejo vadybą per mažai dèmesio skiriama paciento ịgalinimui savarankiškai veikti [44].

Paciento igalinimas. Igalinimo terminas sveikatos priežiūroje suvokiamas kaip procesas, kurio metu sveikatos specialistai keičia paciento elgesį, padèdami jam suprasti ligos prognozę, riziką, išaiškindami gydymo galimybes, skatindami savisaugą, savirūpą, mokydami laikytis gydymo ir mitybos bei fizinio aktyvumo rekomendacijų, stiprinti sveikatą ir jaustis už ją atsakingu. Paciento ịgalinimo standartai turi būti pritaikyti prie kiekvieno padalinio veiklos sričių [45]. Vienas iš pirmujų didesnès apimties paciento ịgalinimo tyrimų Europos Komisijos iniciatyva atliktas 2012 m. penkiolikoje Europos Sajungos šalių narių (Belgijoje, Čekijoje, Suomijoje, Prancūzijoje, Vokietijoje, Graikijoje, Vengrijoje, Italijoje, Latvijoje, Lenkijoje, Rumunijoje, Slovakijoje, Ispanijoje, Jungtinejje Karalysteje, Austrijoje). Tyrimas kokybinis, skirtas ištirti sveikatos priežiūros specialistų ir pacientų patirtị bei nuomonę dèl pacientų igalinimo dalyvauti savo sveikatos priežiūroje. Tyrime dalyvavo po penkis kiekvienos šalies sveikatos priežiūros specialistus ir po dešimt pacientų. Rezultatai atskleide, kad terminas ,pacientu igalinimas“ yra neapibrěžtas, sunkiai suprantamas ir gydytojams, ir pacientams. Neapibrèžta ir pacientų igalinimo nauda sveikatos priežiūros sistemai, tačiau nustatyta, kad pacientai, norèdami būti informuoti apie susirgimą ir suprasti su gydymu susijusius sprendimus, juos patiki profesionalams [46].

Šeimos gydytojai pripažįsta, kad sergantiems lètinèmis ligomis pacientams svarbu dalyvauti sprendimų prièmime, nes tai skatina geresnius gydymosi rezultatus, tačiau pacientai dažniausiai nerodo noro bendradarbiauti ir pasyviai laukia gydytojų nurodymų, aiškindami, kad neturi pakankamai medicinos žinių ir kompetencijos dalyvauti priimant sprendimus [30].

Grupė Lietuvos tyrèjų atliko tiriamają apžvalgą, siekdami išsiaiškinti mokslinį slaugytojo vaidmens ir veiksnių, igalinančių melanoma sergančius pacientus kontroliuoti savo ligą, pagrịstumą. Analizė atskleidè bendruosius slaugytojų vaidmens bruožus: kokybiška priežiūra, psichologinè pagalba, pacientų konsultavimas, reikalingos informacijos teikimas, tikslingas paciento ir jo artimųų mokymas, ligos priežiūros koordinavimas, formuojant ịvairias ligos valdymo strategijas. Pacientu igalinimą valdyti savo ligą ịvairių šalių autoriai nurodo kaip neatsiejamą sveikatos priežiūros dalị, už kurią labiausiai atsakingi slaugytojai [47]. Z. Daruwalla ir kt. (2019) pristate gaires, kaip tolesniam pacientų igalinimui, jų šeimų galimybių stiprinimui ir sveikatos priežiūros sistemų orientavimui ị pacientą gali būti naudojamos sveikatos technologijos [48].

\section{Išvados}

1. Nepaisant dauginio ligotumo paplitimo, jo poveikio pacientams ir sveikatos priežiūros sistemoms, mokslu pagrịsti ịrodymai apie sergančiujų dviem ar daugiau letinių ligu valdymą kol kas riboti.

2. Iki šiol vykdytų priemonių poveikis nebuvo vienareikšmiškai patvirtintas.Tikimasi, kad jos būtų veiksmingesnès, nukreiptos ị rizikos veiksnius ar specifinius funkcinius sunkumus.

3. I pacientą orientuota integruota praktinè priežiūra, atvejų vadyba ir pacientų igalinimas galètų sumažinti sergančiujų priklausomybę nuo institucinès globos, o kartu ir išlaidas, išvengiant nebūtino hospitalizavimo.

4. Pažangi kryptis - stiprinti šeimos gydytojo komandą ir partnerystę su pacientais, iggalinant juos sveikatai palankia elgsena savarankiškai valdyti ligą.

\section{Literatūra}

1. Fortin M, Bravo G, Hudon C, Vanasse A, Lapointe L. Prevalence of multimorbidity among adults seen in family practice. Ann Fam Med2005;3:223-8.

https://doi.org/10.1370/afm.272

2. Wallace E, Salisbury C, Guthrie B, Lewis C, Fahey T, Smith SM. Managing patients with multimorbidity in primary care. BMJ 2015;350:h176.

https://doi.org/10.1136/bmj.h176 


\section{8}

3. Smith SM, Soubhi H,Fortin M, Hudon C, O'Dowd T. Managing patients with multimorbidity: systematic review of interventions in primary care and community settings. BMJ2012;345:e5205.

https://doi.org/10.1136/bmj.e5205

4. O'Connor SJ. Healthcare delivery. J Healthc Manag 2011; 56(6):355-56.

https://doi.org/10.1097/00115514-201111000-00001

5. Taylor AW, Price K, Gill TK, Adams R, Pilkington R, Carrangis $\mathrm{N}$, et al. Multimorbiditynot just an older person's issue. BMC Public Health2010;10:718.

https://doi.org/10.1186/1471-2458-10-718

6. Vogeli C, Shields AE, Lee TA, Gibson TB, Marder WD, Weiss $\mathrm{KB}$, et al. Multiple chronic conditions: prevalence, health consequences, and implications for quality, care management, and costs. J Gen Intern Med2007;22(suppl 3):391-5.

https://doi.org/10.1007/s11606-007-0322-1

7. Menotti A, Mulder I, Nissinen A, Giampaoli S, Feskens EJ, Kromhout D. Prevalence of morbidity and multimorbidity in elderly male populations and their impact on 10 -year all-cause mortality: the FINE study (Finland, Italy, Netherlands, Elderly). J Clin Epidemiol2001;54:680-6. https://doi.org/10.1016/S0895-4356(00)00368-1

8. Sinnige J, Korevaar JC, Westert GP, Spreeuwenberg P, Schellevis FG, Braspenning JC. Multimorbidity patterns in a primary care population aged 55 years and over. Fam Pract 2015; 32(5): 505-513.

https://doi.org/10.1093/fampra/cmv037

9. Sinnige J, Korevaar JC, Westert GP, Spreeuwenberg P, Schellevis FG, Braspenning JC. Multimorbidity patterns in a primary care population aged 55 years and over. Fam Pract 2015; 32(5): 505-513

https://doi.org/10.1093/fampra/cmv037

10. Urbšys B. Dauginėmis ligomis sergančių pacientų polifarmacijos ypatumai. Magistro darbas. LSMU, 2020:44. https://hdl. handle.net/20.500.12512/107344

11. .Lietuvos Respublikos sveikatos apsaugos ministro $2016 \mathrm{~m}$. rugsèjo 26 d. ịsakymasNr. V-1104 Dèl Šeimos medicinos plètros 2016-2025 metų veiksmų plano patvirtinimo.https://eseimas.lrs.lt/portal/legalAct/lt/TAD/0b0610d183f211e6a0f68 fd135e6f40c?jfwid=f4nne6w5

12. Korownyk C, McCormak J, Kolber MR, et al. Competing demands and opportunities in primary care. Can Fam Physician. 2017;63(9):664-668.

13. Maier CL, Aiken LH, Busse R. Nurses in advanced roles in primary care: policy levers for implementation. OECD Publishing, Paris 2017;98

14. Valstybinès ligonių kasos prie sveikatos apsaugos ministerijos direktoriaus 2006 m. kovo 29 d. ịsakymas Nr. 1K-43 Dèl ligų prevencijos programų vykdymo stebėsenos tvarkos aprašo patvirtinimo.
15. LR sveikatos apsaugos ministro ir LR socialinès apsaugos ir darbo ministro $2007 \mathrm{~m}$. liepos $4 \mathrm{~d}$. įsakymas Nr. V-558/A1183 Dẻl slaugos ir socialinių paslaugų bendro teikimo tvarkos aprašo patvirtinimo.Valstybės žinios, 2007-07-10, Nr. 76-3029.

16. Lietuvos Respublikos sveikatos apsaugos ministro $2008 \mathrm{~m}$. lapkričio 26 d. ịsakymas Nr. V-1149 "Dèl Valstybinès lètiniu neinfekciniu ligu profilaktikos 2008-2010 metu programos patvirtinimo". https://e-seimas.lrs.lt/portal/legalAct/lt/TAD/ TAIS.332249?jfwid=-fxdp7jy3

17. Lietuvos Respublikos sveikatos apsaugos ministro $2014 \mathrm{~m}$. vasario 28 d. įsakymas Nr. V-288 "Dèl ilgalaikio pacientų, sergančiu lętinẻmis ligomis, sveikatos būklès stebèjimo tvarkos aprašo patvirtinimo".

18. Valstybinè akreditavimo sveikatos priežiūros veiklai tarnyba. Pirminės ambulatorinès asmens sveikatos priežiūros ịstaigu akreditavimo vadovas. Vilnius, 2015:190.

19. Kriščiūnas A. Negalia ir požiūris i j ją šiuolaikinèje visuomenèje. Sveikatos mokslai, 2015;(1): 5-14.

https://doi.org/10.5200/sm-hs.2015.001

20. Goodwin N, Dixon A, Poole T, Raleigh V. Improving the quality of care in general practice. London, The King's Fund2011.

21. Stewart M, Ryan B. Ecology of health care in Canada. Can Fam Physician 2015;61:449-53.

22. Ewing GB, Selassie AW, Lopez CH, McCutcheon EP. Selfreport of delivery of clinical preventive services by U.S. physicians. Comparing specialty, gender, age, setting of practice, and area of practice. Am J Prev Med 1999;17(1):62-72.

https://doi.org/10.1016/S0749-3797(99)00032-X

23. Østbye T, Yarnall KS, Krause KM, Pollak KI, Gradison M, Michener JL. Is there time for management of patients with chronic diseases in primary care? Ann Fam Med 2005;3(3):209-14.

24. Yarnall KS, Pollak KI, Østbye T, Krause KM, Michener JL. Primary care: is there enough time for prevention? Am J Public Health 2003;93(4):635-41.

https://doi.org/10.2105/AJPH.93.4.635

25. Tricoci P, Allen JM, Kramer JM, Califf RM, Smith Jr SC. Scientific evidence underlying the ACC/AHA clinical practice guidelines. JAMA 2009;301(8):831-41.

https://doi.org/10.1001/jama.2009.205

26. Upshur Ross EG. Do clinical guidelines still make sense? No. Ann Fam Med 2014;12(3):202-3. https://doi.org/10.1370/afm.1654

27. Rubio-Valera M, Pons-Vigués M, Martínez-Andrés M, MorenoPeral P, Berenguera A, FernándezA. Barriers and facilitators for the implementation of primary prevention and health promotion activities in primary care: a synthesis through meta-ethnography. PLoS One 2014;9(2):e89554.

https://doi.org/10.1371/journal.pone.0089554

28. Černiauskaitė J. LSMU Kauno klinikų šeimos medicinos klinikoje dirbančių šeimos gydytojų ir besilankančių pacientu požiūris į medicininès konsultacijos tikslus bei pacientui skirto laiko panaudojimo veiksmingumą. Kaunas: LSMU, 2014:104. 
https://hdl.handle.net/20.500.12512/102713.

29. Jakubynaitė I., Kaselienė S. Ambulatorines paslaugas teikiančių gydytojų specialistų požiūris ị pirminès ir antrinès sveikatos priežiūros grandžių bendradarbiavimą. Visuomenès sveikata, 2016;1(72):29-36.

30. Peičius E., Kučinskaitė A. Lètinėmis neinfekcinėmis ligomis sergančių pacientų dalyvavimas priimant pirminès sveikatos priežiūros sprendimus: kokybinio tyrimo analizè. Visuomenès sveikata, 2014;1 priedas:90-97.

31. Goštautaitė B, Jankauskienė D, Išganaitis V. Projektas "Pacientų ir sveikatos priežiūros paslaugų teikèjų apklausos atlikimas ir analizès parengimas". Pacientų ir sveikatospriežiūros paslaugų teikèjų pasitenkinimo teikiamų paslaugų kokybe bei prieinamumuanalizè (I dalis).http://www.esparama.lt/es_parama_pletra/ failai/ESFproduktai/2012_pacientu_ir_sveikatos_prieziuros_paslaugu_teikeju_pasitenkinimo_teikiamomis_paslaugomis_analize_1.pdf

32. Lietuvos Respublikos valstybès kontrolè. Valstybinio audito ataskaita. Ar efektyvi šeimos gydytojų veikla? 2013.

33. Naylor MD, Kurtzman ET. The role of nurse practitioners in reinventing primary care. Health Aff 2010;29(5):893-9. https://doi.org/10.1377/hlthaff.2010.0440

34. Laurant M, van der Biezen M, Wijers N, Watananirun K, Kontopantelis E, van Vught AJAH. Nurses as substitutes for doctors in primary care. Cochrane Database Syst Rev 2018;(7). https://doi.org/10.1002/14651858.CD001271.pub3

35. Lietuvos Respublikos sveikatos apsaugos ministro $2017 \mathrm{~m}$. liepos 7 d. ịsakymas Nr. V-852 Dèl Lietuvos medicinos normos MN 160:2017, „Išplèstinės praktikos slaugytojas“ patvirtinimo. TAR, 2017-07-12, Nr. 12017.

36. Dubicka A., Stundžienė R., Urbanavičè R. Išplèstinès praktikos slaugytojų integravimo galimybès ị pirminès sveikatos priežiūros ịstaigą. Sveikatos mokslai, 2021;31(2):136-140. https://doi.org/10.35988/sm-hs.2021.053

37. Arsua WK, Chirchir LK, Chebon SK. Determinants of physicians and nurses' professional satisfaction at the moi teaching and referral hospital, Eldoret, Kenya. J Health Med Nurs 2019;64.

38. ACMA. Scope of services. Acmaweb.org. https://www.acmaweb.org/section.aspx?sID=136\&fbclid=IwAR1S78mQ8vN

39. Lietuvos Respublikos Seimo 2011 m. birželio 7 d. nutarimas Dél Lietuvos sveikatos sistemos 2011-2020 metų plètros metmenų patvirtinimo Nr. XI-1430. Valstybès žinios, 2011-06-16, Nr. 73-3498.

40. Štaras K., Vedlūga T. Atvejo vadybininko modelio analizė sveikatos sistemos kontekste.Sveikatos politika ir valdymas, 2012;1(4):116-126.

41. Norkienė S., Petrauskienė D., Norkutè-Macijauskė U. Pirminès asmens sveikatos priežiūros ịstaigos veiklos gerinimas taikant atvejo vadybos modelị. Sveikatos mokslai, 2019; 29(5): 81-89. https://doi.org/10.35988/sm-hs.2019.086

42. Savickaitè A., Česas A. Pirminių onkologinių ligonių sveikatos priežiūros optimizavimo galimybès, taikant atvejo vadybą. Sveikatos mokslai, 2020;30(7):97-104.

https://doi.org/10.35988/sm-hs.2020.184

43. Lukersmith S, Millington M, Salvador-Carulla L. What is case management? A scoping and mapping review. Int J Integr Care 2016;16(4):2.

https://doi.org/10.5334/ijic. 2477

44. Moore ST. A social work practice model of case management: the case management grid. Social Work 1990; 35(5): 444 -8.

45. Monas L, Toren O, Uziely B, Chinitz D. The oncology nurse coordinator: role perceptions of staff members and nurse coordinators. Isr J Health Policy Res 2017;6(1):66.

https://doi.org/10.1186/s13584-017-0186-8

46. Eurobarometer Qualitative Study. Patient Involvement. European Commission aggregate report, TNS Qual+, 2012.

47. Nebilevičiūtė M., Kielė V., Kutkauskienė J. Melanoma sergančių pacientų ligos ir gyvensenos kontrolè. Sveikatos mokslai, 2021; 31(2).

https://doi.org/10.35988/sm-hs.2021.056

48. Daruwalla Z, Thakkar V, Aggarwal M, Kiasatdolatabadi A, Guergachi A, Keshavjee K. Patient empowerment: the role of technology. Stud Health Technol Inform 2019;257:70-74.

\section{OPPORTUNITIES OF MANAGING CHRONIC NON- COMMUNICABLE DISEASES IN PRIMARY CARE \\ R. Baltušienė, M. Buitkus, V. Dringelis,}

\section{A. Kaltanienè, T. Subočiūtè-Stuliova}

Keywords: multimorbidity, chronic non-communicable diseases, chronic disease managament, case manager, integrated care models, patient empowerment.

Summary

Primary care providers currently are not prepared to address complex public health problems of aging population, therefore many countries around the world are strengthening the primary care services in a number of ways to improve access to and quality of service. The aim of this study is to find science-based evidence on the effectiveness of interventions in primary care to meet the needs of comorbid patients with two or more chronic non-communicable diseases. The research was conducted in period from 2005 to 2021. The research used data from research conducted in Lithuania and foreign countries, corresponding to the topic and national legislation governing the management of chronic non-communicable diseases. The outcome of this research are four options for improving the management of chronic diseases: 1) strengthening the team of family doctors by involving nursing and social service workers and delegating some of their functions to them; 2) integration of an advanced practice nurse into the primary care services; 3) application of the case management model; 4) empowerment of the patients to independently manage the disease.

Correspondence to: tatjana.subociute-stuliova@vrm.lt

Gauta 2021-05-12 